\title{
Fístula sinocutânea no seio maxilar caudal - relato de caso
}

Campo Amor Vieira da Cunha Neto", Giovane Olivo, César Erineudo Tavares de Araújo

Faculdade de Medicina Veterinária e Zootecnia, Universidade Estadual Paulista (UNESP), Botucatu, SP, Brasil

*Autor correspondente

e-mail: campoamor_vieira@hotmail.com

\section{Resumo}

As fístulas sinocutâneas geralmente são sequelas de fraturas cominutivas dos ossos da face compostos pelos seios paranasais. 0 maior deles é o seio maxilar caudal (SMC), que se comunica com o seio conchal ventral através do canal infraorbital, e tem seu piso formado pelas raízes dos dentes P4 e M1 cobertas por fina camada óssea. A prevalência de desordens primárias dos seios paranasais decorrentes de trauma é de 6,5\% e os sinais clínicos incluem assimetria facial, edema, epífora, epistaxe ou secreção mucopurulenta unilateral. 0 tratamento consiste em reparo por segunda intenção de fístulas com menos de $3 \mathrm{~cm}$ e cirurgia para fistulas maiores que $3 \mathrm{~cm}$ de diâmetro; as técnicas usualmente descritas são os retalhos de pele, periósteo, músculo e fáscia. Também é possível a realização de enxertos autógenos ou implantes de materiais sintéticos para ancorar o tecido de granulação neoformado. Este trabalho teve por objetivo relatar um caso de correção cirúrgica de fistula sinocutânea crônica em égua da raça Quarto de Milha, com histórico de trauma na face ocorrido há aproximadamente dez meses. A égua estava em bom estado corpóreo, com parâmetros vitais dentro da normalidade e discreta assimetria dos ossos da face. A fístula sinocutânea do SMC esquerdo apresentava falha óssea de $37 \mathrm{~mm}$ e completa cicatrização pele-mucosa, com conteúdo mucopurulento sendo drenado. Uma semana antes do procedimento, foi instituído antibioticoterapia por VO com sulfametaxazol + trimetropim na dose de $25 \mathrm{mg} \cdot \mathrm{kg}^{-1}$ BID e limpeza da ferida com solução de $1 \%$ de iodo em cloreto de sódio 0,9\%, seguida de aspersão de rifamicina sódica TID. Para o procedimento de correção da fístula, o animal foi submetido a jejum alimentar de 6 horas e foi realizada sedação com 0,05 mg.kg-1 de acepromazina IM e 0,05 mg.kg-1 de diazepan IM; após 10 minutos, administrou-se 1 mg. $\mathrm{kg}^{-1}$ de xilazina IV, e após sedação foi realizada a tricotomia da região peri-fistular. Com o animal em estação, foi realizada anestesia local com cloridrato de lidocaína $2 \%$ nos seguintes pontos: entre a linha média frontal e canto medial do olho esquerdo $(5 \mathrm{ml})$, no forame infraorbitário $(5 \mathrm{ml})$, forame supraorbitário $(2 \mathrm{ml})$, terço 
médio da crista facial $(5 \mathrm{ml})$ e processo do osso zigomático $(5 \mathrm{ml})$. Com o animal devidamente sedado, contido e com campo cirúrgico devidamente preparado, foi realizada antissepsia local, incisão de pele na transição pele-mucosa em torno da fístula, divulsão da pele, tecido conectivo e elevação do periósteo. A síntese foi realizada em duas linhas com sutura em massa da pele, tecido conectivo e periósteo com padrão Wolf, captonadas e outra simples separada de pele, ambas com fio náilon número zero. Para o pósoperatório, foi dado continuidade na antibioticoterapia durante duas semanas, reduzindo a dose inicial para $20 \mathrm{mg} \cdot \mathrm{kg}^{-1}$, flunixin meglumine 1,1 mg.kg-1 IV SID durante três dias, seguido de meloxican 1,2 mg. $\mathrm{kg}^{-1}$ SID durante cinco dias, além de omeprazol 10\% SID por VO. Para os curativos foi utilizado PVPI tópico e glicerina iodada a $2 \%$, compressão da ferida com bandagens coladas com adesivo de cianocrilato, trocados a cada 48 horas, durante duas semanas. As suturas foram retiradas com 10 dias de PO. Após retirada das suturas, observou-se uma solução de continuidade pontual na parte cranial da linha de síntese, onde foi realizada limpeza e preenchimento com cianocrilato. Aos 15 dias de pós-operatório, foi possível verificar, com o auxílio de ultrassonografia, que a falha óssea foi preenchida com tecido de granulação sob o tecido cicatricial da epiderme. A técnica utilizada foi de fácil execução, permitiu ser realizada com o animal sedado em estação e se mostrou eficiente na correção de fístula crônica, com aproximadamente $3 \mathrm{~cm}$ de diâmetro, no seio maxilar caudal, com a vantagem de manter o animal na propriedade, evitando maiores transtornos de viagem e diminuindo os custos para o proprietário.

Palavras-chave: Fístula. Cirurgia. Trauma. 